\title{
Comparative Study of Efficacy of Nebulized Beta 2 Agonist vs Nebulized Adrenaline in Bronchiolitis
}

\author{
Authors \\ Dr Aamir Ali ${ }^{1}$, Dr Kumar Shambhu Nath ${ }^{2}$, Dr Ashit Kumar ${ }^{3}$ \\ ${ }^{1}$ PGT, Third Year, Deptt of Pediatrics, KMCH \\ ${ }^{2}$ Associate Professor, Deptt of Pediatrics, $\mathrm{KMCH}$ \\ ${ }^{3}$ Senior Resident, Deptt of Pediatrics, KMCH
}

\section{Introduction}

Bronchiolitis is an acute communicable disease predominantly manifesting in infancy mainly caused by RSV and characterized by cough, coryza, fever, grunting, tachypnoea, retractions, inspiratory crackles, expiratory wheezes and air trapping. Other infectious agents associated with bronchiolitis are parainfluenza (type 1,2,3) mycoplasma pneumonia.

An estimated 150 million new cases of bronchiolitis occur annually worldwide out of which 10-20 million are severe enough to require hospitalization.

In India epidemics occur in winter and monsoon and may last for 1 to 5 month peaking in month of February.

It is more common in boys than girls, in babies who are bottle fed and in children who lives in crowded urban areas. (Stanley J.Snierzewski;JUNE 2011)

It is generally a self limiting condition and in most cases the clinical picture improves within one week.

Acute bronchiolitis is characterized by bronchiolar obstruction due to edema with or without spasm, accumulation of mucus and cellular debris and by invasion of bronchioles by virus.
Treatment of infants with bronchiolitis is largely supportive and symptomatic with minimal handling, proper position, supplementation of cool and humidified oxygen, adequate hydration, care of secretion, ventilator support, careful and frequent monitoring of infant.

\section{Aims and Objective}

To compare the efficacy of nebulized salbutamol and adrenaline in bronchiolitis

\section{Materials and Method}

The study was conducted in children aged 0-2yrs diagnosed with bronchiolitis in department of Paediatrics, Katihar Medical College, Katihar

Study Period: Between December 2016 to February 2017

Sample Size: 60 patients diagnosed with bronchiolitis were divided into 2 groups $\mathrm{A}$ and $\mathrm{B}$.

Inclusion Criteria: Children between the ages of 0-2 years diagnosed as bronchiolitis based on the history of coryza and fever followed by respiratory distress.

\section{Exclusion Criteria}

a. History of diagnosed case of asthma.

b. History of foreign body inhalation. 
c. History of repeated aspiration or vomiting.

d. Children with history of two or more respiratory distress or wheezing.

e. Presence of chronic cardiovascular or respiratory conditions like CHD, lung cysts etc.

f. Previous use of bronchodilators and glucocorticoids.

Children were randomly assigned into 2 groups A and B. Each group consisted of 30 patients.

Group A received nebulized $0.5 \mathrm{mg}$ of $0.1 \%$ adrenaline solution $(0.5 \mathrm{ml}$ in 3.5 normal saline) delivered by nebulizer

Group B received $2.5 \mathrm{mg}$ nebulized salbutamol $(0.5 \mathrm{ml}$ in 3.5 normal saline) delivered by nebulizer

Prior to each drug administration and after administration (nebulisation at 0,30 and 60 minutes) RDAI score, RR ,Spo2, and HR were recorded.

A comparison between observations before and after intervention in the given groups and between the two groups was done.

Data thus collected were compiled in microsoft excel worksheet 2007 and analysed. P value $<0.05$ was significant.

\section{Observations and Results}

Distribution of age according to group A

\section{Group A}

0 to 6 month $\quad 7$ to 12 month

$\square 13$ to 18 month $\square 19$ to 24 month

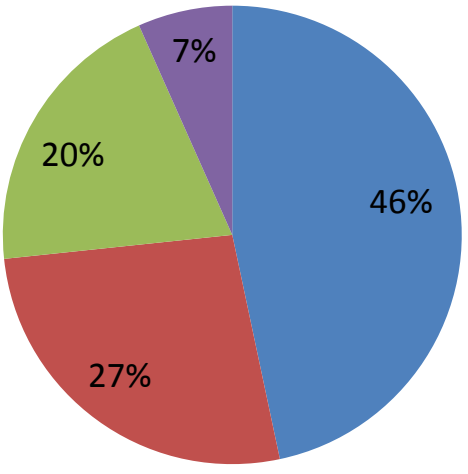

Distribution of age according to group B

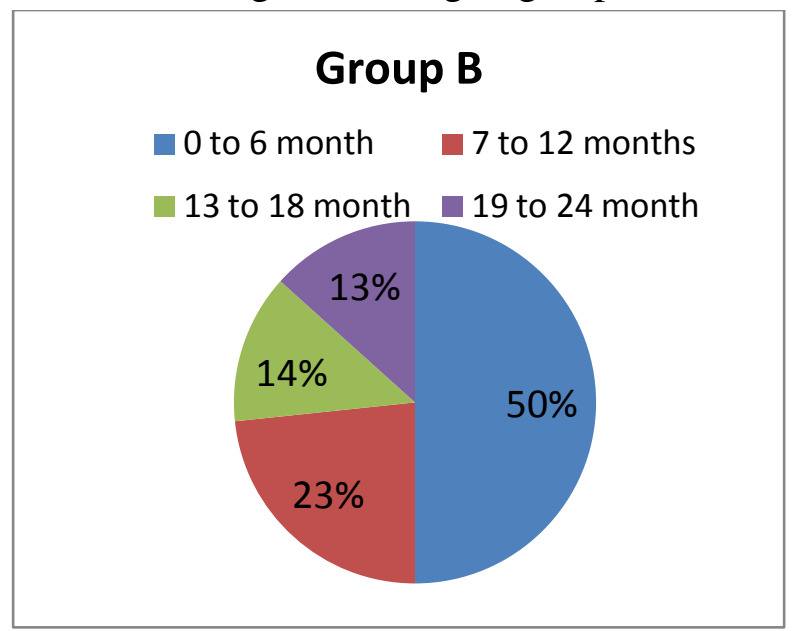

Table 1: Initial mean and standard deviation of Respiratory status in the two groups.

\begin{tabular}{|c|c|c|c|c|}
\hline Group & $\begin{array}{l}\mathrm{HR} / \mathrm{m} \\
\text { in }\end{array}$ & $\begin{array}{l}\mathbf{R R} / \mathbf{m} \\
\text { in }\end{array}$ & $\begin{array}{l}\text { RDAI } \\
\text { score }\end{array}$ & $\begin{array}{l}\mathrm{SpO}_{\%} \\
\%\end{array}$ \\
\hline $\begin{array}{l}\text { Group } \\
\text { A }\end{array}$ & $\begin{array}{l}154.10 \\
\pm 4.70\end{array}$ & $\begin{array}{l}75.83 \\
\pm 8.03\end{array}$ & $\begin{array}{l}11.86 \pm \\
1.87\end{array}$ & $\begin{array}{l}87.70 \\
\pm 2.18\end{array}$ \\
\hline $\begin{array}{l}\text { Group } \\
\text { B }\end{array}$ & $\begin{array}{l}153.70 \\
\pm 5.07\end{array}$ & $\begin{array}{l}78.86 \\
\pm 8.8\end{array}$ & $\begin{array}{l}11.56 \pm \\
1.54\end{array}$ & $\begin{array}{l}86.76 \\
\pm 3.14\end{array}$ \\
\hline t-value & 0.31 & 1.39 & 0.54 & 1.34 \\
\hline $\begin{array}{l}\mathrm{p}- \\
\text { value }\end{array}$ & $\begin{array}{l}\text { Not } \\
\text { significa } \\
\text { nt }\end{array}$ & $\begin{array}{l}\text { Not } \\
\text { significa } \\
\text { nt }\end{array}$ & $\begin{array}{l}\text { Not } \\
\text { significa } \\
\text { nt }\end{array}$ & $\begin{array}{l}\text { Not } \\
\text { significa } \\
\text { nt }\end{array}$ \\
\hline
\end{tabular}

Table 2: Changes in respiratory parameters after 3 initial nebulisation.

\begin{tabular}{|c|c|c|c|c|}
\hline Group & $\begin{array}{l}\mathbf{H R} / \mathbf{m} \\
\mathrm{in}\end{array}$ & $\underset{\mathbf{n}}{\mathbf{R}} \mathbf{R} / \mathbf{m i}$ & $\begin{array}{l}\text { RDAI } \\
\text { score }\end{array}$ & $\begin{array}{l}\mathrm{SpO}_{\%} \\
\%\end{array}$ \\
\hline Group & $\begin{array}{l}162 \\
\pm 4.25\end{array}$ & $\begin{array}{l}56.76 \\
\pm 3.68\end{array}$ & $\begin{array}{l}7.13 \pm \\
1.92\end{array}$ & $\begin{array}{l}94.46 \\
\pm 2.33\end{array}$ \\
\hline $\begin{array}{l}\text { Group } \\
\text { B }\end{array}$ & $\begin{array}{l}160.03 \\
3 \pm 4.34\end{array}$ & $\begin{array}{l}66.33 \\
\pm 3.27\end{array}$ & $\begin{array}{l}7.80 \pm \\
1.59\end{array}$ & $\begin{array}{l}88.66 \\
\pm 3.04\end{array}$ \\
\hline t-value & 1.77 & 10.64 & 1.47 & 8.29 \\
\hline $\begin{array}{l}\text { p- } \\
\text { value }\end{array}$ & $\begin{array}{l}\text { Not } \\
\text { significa } \\
\text { nt }\end{array}$ & $<0.001$ & $\begin{array}{l}\text { Not } \\
\text { significa } \\
\text { nt }\end{array}$ & $<0.001$ \\
\hline
\end{tabular}

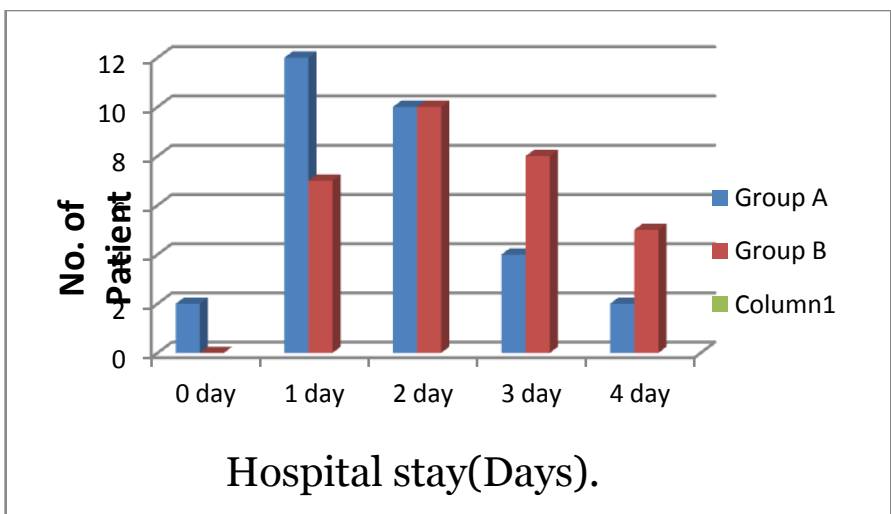


Sixty children in the age range 0-24 month were included in the study with 30 in each group and most of the children were below 6 months of age.

The two groups were comparable with respect to their mean initial HR, RR, RDAI score and SpO2 (Table 1)

In group 1 postnebulisation mean $\mathrm{HR}$, increased to $162 \pm 4.25$ from $154 \pm 4.70$ per min, the mean respiratory rate decreased to $56.76 \pm 3.68$ from $75.83 \pm 8.03$ per min, mean RDAI score decreased to $7.13 \pm 1.92$ from $11.86 \pm 1.87$ and the mean $\mathrm{SpO} 2$ $\%$ increased to $94.46 \pm 2.33$ from $86.76 \pm 3$. 14 .

In group2 there was a similar change after initial nebulisation with mean heart rate increasing to $160.033 \pm$ from $153.7 \pm 5.07$ per min, mean RR decreasing to $66.33 \pm .27$ from $78.86 \pm 8.8$ per min, mean RDAI score decreased to $7.80 \pm 1.59$ from $11.56 \pm 1.54$ and mean $\mathrm{SpO} 2 \%$ increased to $88.66 \pm 3.04$ from $86.76 \pm 3.14$.

On analysis there was no significant difference in change of $\mathrm{HR}$, but there was a significant difference in the change in $\mathrm{RR}$ and $\mathrm{SpO} 2$ favouring adrenaline group. (Table2)

\section{Conclusion}

Hence from above observations and results we conclude that nebulised adrenaline is a useful and safe drug for bronchiolitis and is superior to salbutamol.

\section{References}

1. Colette C. Mull, MD; Richard J. Scarfone, MD; Lara R. Ferri, MD; et al: A Randomized trial of nebulized epinephrine vs albuterol in the Emergency Department, treatment of bronchiolitis: Arch Pediatr Adoles Med.2004;158(2):113-118. DOI:10.1001/archipedi.158.2.113

2. Claire Wain Wright ,M.B, B.S, MD;Luis Altamirano, Medico-Cirujano, Marise Cheney, B.Nurs. M.P.H; et al:A Multicentre randomized double blinded controlled trial of nebulized epinephrine in infants with acute Bronchiolitis:July 3,2003,N Eng L, J Med 2003;349:27-35

3. Paul Walsh, MB,Bch,BAO,John Caldwell, Pharm D,Kennedy K. McQuillan, MD, Steven Friese MD,Dale Robbins PA-C, Stephen J. Rothenberg, PhD; Comparison of Nebulized epinephrine to Albuterol in Bronchiolitis :2008 by the society for Academic Emergency Medicine.DOI10.1111/j-1553-2712.2008.00064x

4. Mohammad -Reza Modaressi, MD, Asadola Asadian MD, Jamal Faghihinia MD, Mehrshd Arashpour and Firoozeh Mousavinusab MD; Comparison of epinephrine to salbutamol in acute bronchiolitis: Iran J Pediatr.2012 JUNE; 22(2):241-244:PMCID:PMC 3446067

5. Menon K Sutcliffe $T$ Klassen TP A randomized trial comparing the efficacy of epinephrine with salbutamol in the treatment of acute bronchiolitis. J Pediatr. 1995;1261004- 1007. PubMedArticle

6. Ray SM Singh V Comparison of nebulized adrenaline versus salbutamol in wheeze associated respiratory tract infection in infants. Indian Pediatr. 2002;3912- 22. PubMed. 